\title{
Behavior of Fish Meat Components during Manufacture of Frozen Surimi through Processing with $\mathrm{CaCl}_{2}$-Washing
}

\author{
Hiroki Saeki* and Fumio Hirata \\ Central Research Institute, MARUHA Corporation, Wadai, Tsukuba, Ibaraki 300 42, Japan \\ (Received December 9, 1993)
}

White croaker and walleye pollack frozen surimis were manufactured with $\mathrm{CaCl}_{2}$-washing of the minced meat. The behavior of several components in the fish meat during manufacturing was then investigated.

$\mathrm{CaCl}_{2}$ rapidly permeated into the minced meat and prevented the washed meat effectively from swelling during the washing processes. The greater the Ca content of the washed meat, the easier it was to remove the water during the dehydrating process. Simultaneously, the concentration of myofibrillar protein in the materials was caused by elution of water-soluble protein from the same meat. Such behavior was affected by the suppression of swelling of the washed meat by $\mathrm{CaCl}_{2}$. Thus, the myofibrillar protein content and the myofibrillar Ca-ATPase total activity of the frozen surimi increased, although a slight denaturation of the myofibrillar $\mathrm{Ca}$-ATPase of the materials could not be avoided due to $\mathrm{CaCl}_{2}$ washing of the minced meat.

These reuslts suggest that the efficiency of manufacturing frozen surimi and the quality of the surimi based-products could be improved by adopting this method under appropriate conditions.

Key words: frozen surimi, fish meat, myofibrils, calcium chloride, white croaker, walleye pollack

Recently, it was reported that the gel-forming ability of frozen surimi could be significantly improved by washing the raw material fish meat in an aqueous solution containing $\mathrm{CaCl}_{2}$ during the manufacturing process. ${ }^{1)}$ In order to understand the principle of the process, the authors have tried to clarify the influence of $\mathrm{CaCl}_{2}$ on the biochemical properties of fish myofibrillar protein. ${ }^{2-4)}$ According to our previous reports, when the myofibrils were suspended in a low ionic strength solution, the water-holding capacity of the myofibrils could be controlled by changing the $\mathrm{CaCl}_{2}$ concentration together with the ionic strength of the solution without a large denaturation of the myofibrillar protein. It was also found that fish myofibrillar protein was slightly denatured in the presence of $\mathrm{Ca}^{2+}$, and the more labile it became by $\mathrm{CaCl}_{2}$, the lower its thermal stability.

We studied the changes in fish meat components during the manufacture of frozen surimi with $\mathrm{CaCl}_{2}$-washing of the minced meat and discuss the role of $\mathrm{CaCl}_{2}$ on the quality of frozen surimi-based products.

\section{Materials and Methods}

\section{Method of Manufacturing Frozen Surimi}

An outline of the procedure for manufacturing frozen surimi is shown in Fig. 1. Fresh minced meat of white croaker Argyrosomus argentatus and walleye pollack Theragra chalcogramma was washed in four volumes of cold aqueous solution of 0,5 , or $15 \mathrm{mM} \mathrm{CaCl}_{2}$ at $5^{\circ} \mathrm{C}$. The ionic strength of the solution was adusted to 0.06 by adding $\mathrm{NaCl}$. This composition was determined on the basis of the data obtained in the previous studies. ${ }^{3,4}$ After stirring for $10 \mathrm{~min}$, the washed meat was trapped by a nylon screen and resuspended in the same solution for the second washing. The washed meat thus obtained, called once-washed and twice-washed meat in the following figures, was dehydrated with a hydraulic press at $50 \mathrm{~kg} / \mathrm{cm}^{2}$ for $40 \mathrm{~min}$ at $8-10^{\circ} \mathrm{C}$. Frozen surimi was prepared by mixing the dehydrated meat with $8 \%$ sorbitol and $0.2 \%$ polyphosphate (Mascolin F-80NB, Taiyo Chemical Industry Co., Ltd.), followed by freezing quickly at $-30^{\circ} \mathrm{C}$.

\section{Preparation of Myofibrils}

Myofibrils were quantitatively prepared from the raw materials at each processing step and from the forzen surimi in the same manner described by Katoh et al. ${ }^{\text {s) }}$ They were suspended in $0.16 \mathrm{M} \mathrm{KCl}, 40 \mathrm{~mm}$ Tris-maleate (pH 7.0) and subjected to the following experiments.

\section{Measurement of Ca Content}

The $\mathrm{Ca}$ content was determined by atomic absorption in an air-acetylene flame. ${ }^{6)}$ A $10 \mathrm{~g}$ sample was passed through a screen (mesh size $65 \mu \mathrm{m}$ ) to remove impurities before anaysis.

Determination of Fish Meat Component

Moisture content was measured by drying the sample at $105^{\circ} \mathrm{C}$ for $22 \mathrm{~h}$ Crude protein content was determined by the Kjeldahl method using a conversion factor of 6.25. Myofibrillar protein content was determined by the Biuret method. "Water-soluble protein content of the materials at each step was calculated as the difference between the contents of crude protein and myofibrillar protein.

Measurement of Myofibrillar Ca-ATPase Activity

The Ca-ATPase assay was performed at $25^{\circ} \mathrm{C}$ in a mixture containing $0.1 \mathrm{M} \mathrm{KCl}, 5 \mathrm{~mm} \mathrm{CaCl}, 1 \mathrm{~mm}$ ATP, $25 \mathrm{~mm}$ Tris-maleate (pH 7.0), and $0.2-0.3 \mathrm{mg} / \mathrm{ml}$ myofibrils. The reaction was stopped by adding $\mathrm{HClO}_{4}$ to a final concentration of $5 \%$. The inorganic phosphate liberated was measured by the method of Gomori. ${ }^{8}$ The myofibrillar Ca-ATPase specific activity and its total activity of the flesh were expressed as $\mu \mathrm{mol} \mathrm{Pi}$ liberation $/ \mathrm{min} \cdot \mathrm{mg}$ of myofibrillar protein and $\mu \mathrm{mol}$ Pi liberation $/ \mathrm{min} \cdot 5 \mathrm{~g}$ of sample wet weight. ${ }^{9)}$

\section{Results}

Permeation of Ca into Materials during Washing Process

Changes in the $\mathrm{Ca}$ content of minced fish meat while manufacturing frozen surimi are shown in Fig. 2. The Ca content of the mined meats of the raw material was 


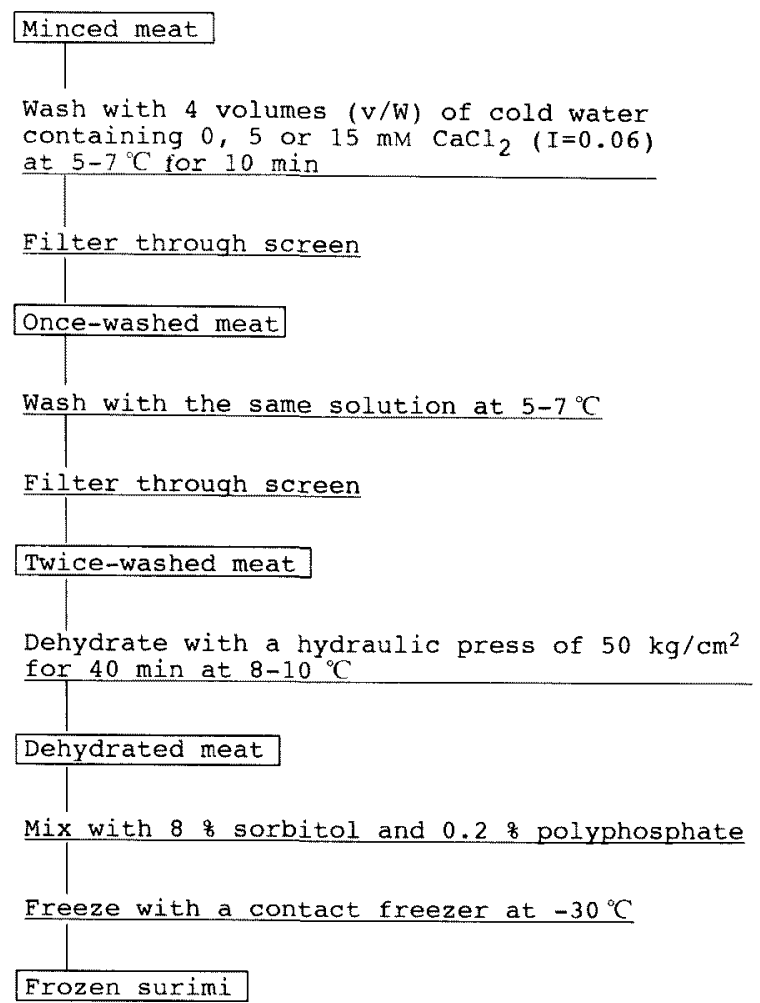

Fig. 1. Outline of procedure for processing frozen surimi.

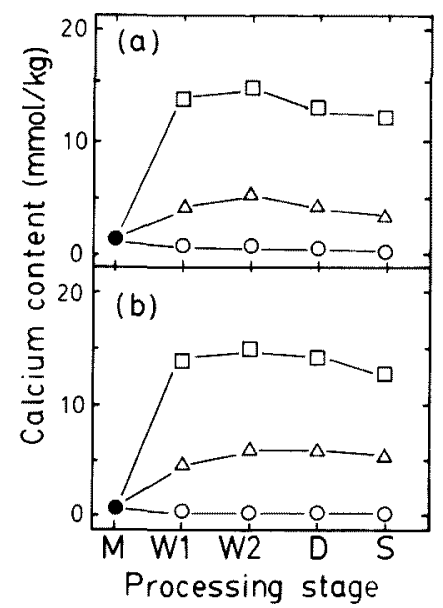

Fig. 2. Change in $\mathrm{Ca}$ content of minced meat during $\mathrm{CaCl}_{2}$-washing of frozen surimi.

The minced meats of white croaker (a) and walleye pollack (b) were washed with four volumes $(\mathrm{v} / \mathrm{w})$ of cold water containing $0(\mathrm{O}), 5$ $(\triangle)$, or $15(\square) \mathrm{mM} \mathrm{CaCl}_{2}$ as shown in Fig. 1. The Ca content of the minced meat from each stage of processing the frozen surimi was measured by atomic absorption spectrophotometry ${ }^{6}$ and expressed as $\mathrm{mmol} / \mathrm{kg}$ wet weight of the specimen. $\mathrm{M}$, minced meat (-) W once-washed meat; W2, twice-washed meat; D, dehydrated meat; S, frozen surimi.

$2.1 \mathrm{mmol} / \mathrm{kg}$ and $0.9 \mathrm{mmol} / \mathrm{kg}$ for white croaker and walleye pollack, respectively. When the minced meat was not washed with $\mathrm{CaCl}_{2}$, the content decreased with the washing processes, and the $\mathrm{Ca}$ content of the dehydrated meats decreased to $0.2 \mathrm{mmol} / \mathrm{kg}$. On the contrary, the $\mathrm{Ca}$

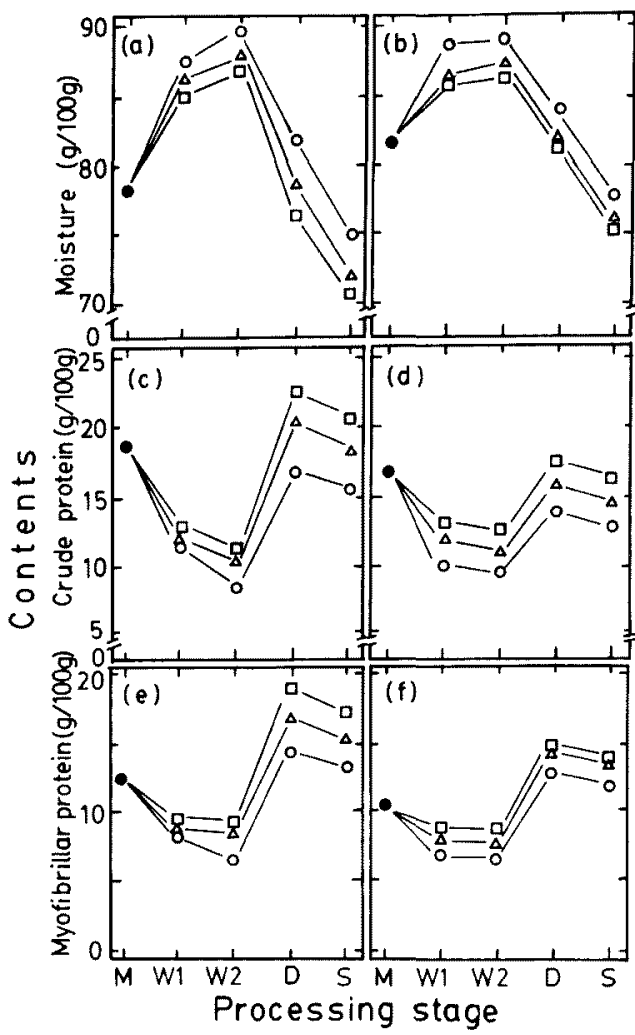

Fig. 3. Changes in moisture, crude protein and myofibrillar protein contents of minced meat during $\mathrm{CaCl}_{2}$-washing of frozen surimi.

The minced meats $(O)$ of white croaker $(a, c, e)$ and walleye pollack $(b, d, f)$ were washed with cold water containing $0(O), 5(\triangle)$, or $15(\square) \mathrm{mM} \mathrm{CaCl}_{2}$ as shown in Fig. 1. Myofibrillar protein was quantitatively prepared from the minced meat by the method of Katoh et al. ${ }^{5)}$ The calcium content of the minced meat was measured as shown in Fig. 2. Alphabetic codes used are the same as in Fig. 2.

content of the minced meats increased with the washing processes when they were washed in an aqueous solution containing $\mathrm{CaCl}_{2}$. The $\mathrm{Ca}$ content of the washed and the dehydrated meats was roughly equal to that of the washing solution. These results indicate that the $\mathrm{Ca}^{2+}$ in the washing solution rapidly permeated into the materials and passed into the frozen surimi.

\section{Changes in Moisture, Crude Protein, and Myofibrillar Protein Contents of Materials and Frozen Surimi}

As shown in Fig. 3(a,b), the minced meats of white croaker and walleye pollack rapidly absorbed the water during the first washing process, and their moisture content increased when washed again with the same solution. However, the addition of $\mathrm{CaCl}_{2}$ to the washing solution prevented the washed meat effectively from swelling, regardless of the $\mathrm{CaCl}_{2}$ concentration of the washing solution. It was also confirmed that the greater the $\mathrm{Ca}$ content of the washed meat, the easier it was to remove the water in the dehydrating process. Moreover, Fig. 3 (c, $d, e, f)$ clearly shows that the crude protein and myofibrillar protein in the meats increased with increasing the $\mathrm{Ca}$ content of the washed meat. 
Elimination of Water-Soluble Protein and Concentration of Myofibrillar Protein

Generally, the myofibrillar protein content of frozen surimi can be increased by removing lipid and water-soluble protein from the materials. ${ }^{10-12)}$ Changes in the watersoluble protein and myofibrillar protein contents of the material during manufacturing were then investigated. The water-soluble protein and myofibrillar protein contents of the materials at each stage were measured by presuming the moisture in the specimen to be regulated to $78.1 \%$ for white croaker or $81.8 \%$ for walleye pollack. ${ }^{12)}$ The results are shown in Figs. 4 and 5.

The elimination of water-soluble protein from the materials at each processing stage is shown in Fig. 4 . The decrease of water-soluble protein reached about $50 \%$ for

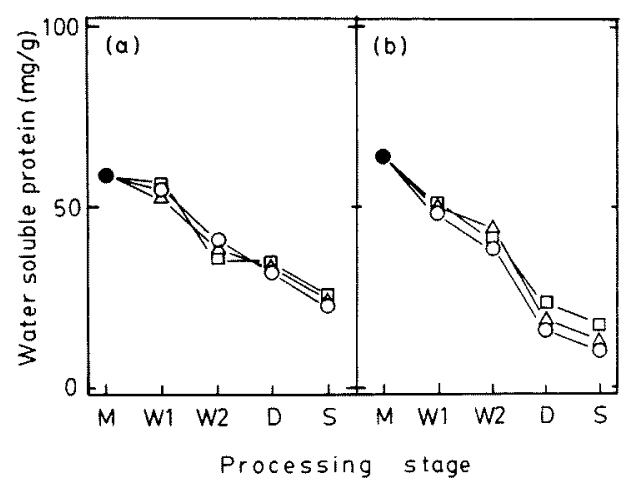

Fig. 4. Change in water soluble protein content of minced meat during $\mathrm{CaCl}_{2}$-washing of frozen surimi.

The minced meats (O) of white croaker (a) walleye pollack (b) were washed with cold water containing $0(\mathrm{O}), 5(\triangle)$ or $15(\square) \mathrm{mM} \mathrm{CaCl}_{2}$ as shown in Fig. 1. The content of water soluble protein of the minced meat at each stage was calculated as the difference between the contents of the crude protein and myofibrillar protein, and measured by assuming the moisture in the specimen to be regulated to $78.1 \%$ (for white croaker) and $81.8 \%$ (for walleye pollack). Alphabetic codes used are the same as in Fig. 2.

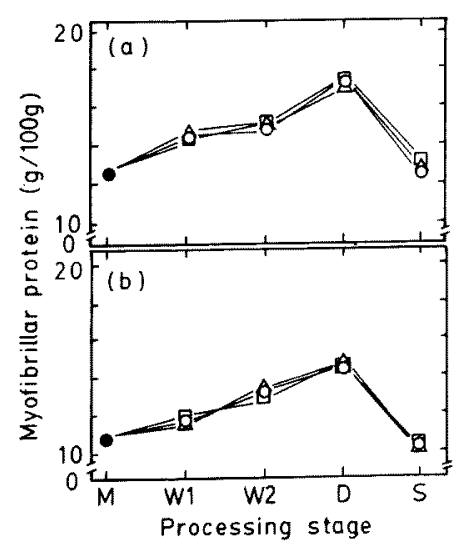

Fig. 5. Change in myofibrillar protein content of minced meat during $\mathrm{CaCl}_{2}$ wwashing of frozen surimi.

The minced meats (O) of white croaker (a) and walleye pollack (b) were washed with cold water containing $0(0), 5(\triangle)$, or 15 (口) $\mathrm{mM} \mathrm{CaCl}_{2}$ as shown in Fig. 1. The myofibrillar protein content of the mined meat at each stage was measured by assuming the moisture in the specimen to be regulated to $78.1 \%$ (for white croaker) and $81.8 \%$ (for walleye pollack). Alphabetic codes used are the same as in Fig. 2. white croaker and $60 \%$ for walleye pollack during manufacturing. On the contary, as shown in Fig. 5, the myofibrillar protein content of the materials increased during the washing and dehydrating processes. Each of the dehydrated meats contained about 1.3 times more myofibrillar protein than that of the minced meats, and the concentration of myofibrillar protein was not influenced by the rate of $\mathrm{Ca}^{2+}$ permeation into the materials. Moreover, the sum of the water-soluble protein contents of the materials was almost identical throughout processing, that is, the value was $19 \mathrm{~g} / 100 \mathrm{~g}$ wet weight for white croaker and $17 \mathrm{~g} / 100 \mathrm{~g}$ for walleye pollack. These results indicate that the concentration of myofibrillar protein in the minced meat was caused by the elution of water-soluble protein from the same meat, and this behavior was not suppressed by $\mathrm{CaCl}_{2}$ washing of the minced meat.

\section{Effluent Loss of Myofibrillar Protein}

Many fine meat particles suspended in the waste fluids were observed during the washing and dehydrating processes. In order to determine the amount of effluent loss of myofibrillar protein, the total amount of myofibrillar protein remaining in the materials was measured at each stage; the results are shown in Fig. 6. In both fish minces, the total amount of myofibrillar protein in the materials decreased with the processing stages regardless of the $\mathrm{Ca}$ concentration of the washing solution. However, it was apparent that the extent of effluent loss of myofibrillar protein during manufacturing decreased due to $\mathrm{CaCl}_{2}$ washing of the minced meat. This result shows that effluent loss of myofibrillar protein in waste fluids can be effectively suppressed by adding $\mathrm{CaCl}_{2}$ in the washing solution.

\section{Changes in Myofibrillar Ca-ATPase Activities}

As shown in Fig 7(a), the slight decrease in myofibrillar Ca-ATPase specific activity of white croaker occurred as

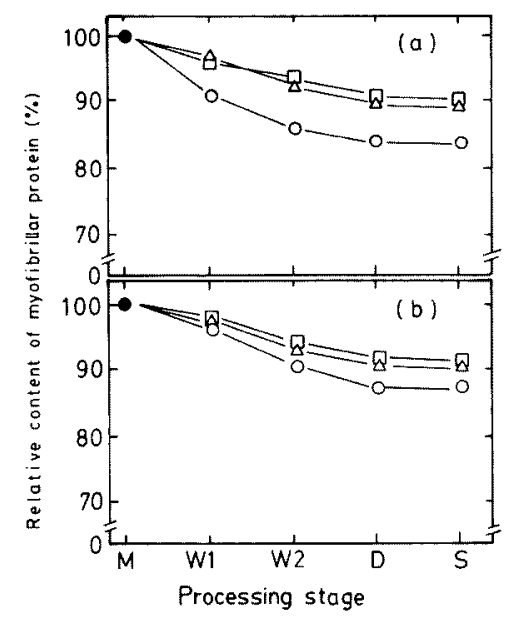

Fig. 6. Change in relative content of myofibrillar protein during $\mathrm{CaCl}_{2}$-washing of frozen surimi.

The minced meats (O) of white croaker (a) and walleye pollack (b) were washed with cold water containing $0(0), 5(\triangle)$, or 15 (口) $\mathrm{mm} \mathrm{CaCl}_{2}$. The myofibrillar protein content at each stage of processing the frozen surimi was measured by the method of Katoh et $a l^{5)}$ The relative content of myofibrillar protein was expressed by taking the myofibrillar protein content of the minced meat before washing as $100 \%$. Alphabetic codes used are the same as in Fig. 2. 


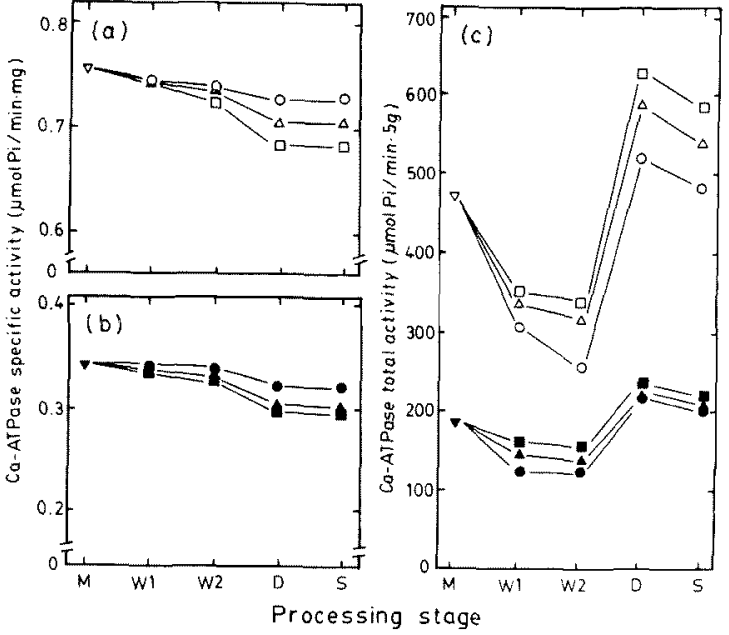

Fig. 7. Changes in myofibrillar Ca-ATPase activities of minced meat during $\mathrm{CaCl}_{2}$-washing of frozen surimi.

The minced meats $(\nabla, \nabla)$ of white croaker and walleye pollack were washed with cold water containing $0(O, \Theta), 5(\triangle, A)$, or 15 $(\square, \square) \mathrm{mM} \mathrm{CaCl}_{2}$ as shown in Fig. 1. The myofibrillar Ca-ATPase specific activity (a, white croaker; $b$, walleye pollack) and its total activity (c) of minced meat were expressed as $\mu \mathrm{mol} \mathrm{Pi}$ liberation $/ \mathrm{min}$. $\mathrm{mg}$ of myofibrillar protein and $\mu \mathrm{mol}$ Pi liberation $/ \mathrm{min} \cdot 5 \mathrm{~g}$ of sample wet weight, respectively. Alphabetic codes used are the same as in Fig. 2.

White circles, white croaker; black circles, walleye pollack.

the Ca content of the materials increased during manufacturing. These trends were also observed in the manufacture of walleye pollack frozen surimi, as shown in Fig. 7(b). These results suggest that the denaturation of myofibrillar protein in these fish meats is accelerated by $\mathrm{CaCl}_{2}$-washing of minced meat during manufactuing of frozen surimi. Nevertheless, the total activity of myofibrillar Ca-ATPase of the materials definitely increased with increasing $\mathrm{Ca}$ content of the meat. Moreover, the change in the total activity of myofibrillar Ca-ATPase of specimens at a fixed moisture content was similar to the change in myofibrillar protein content. These reuslts indicate that the degree of increase in myofibrillar proten content of the fish meats closely reflects the increase in the total ATPase activity of myofibrillar protein.

\section{Discussion}

Eliminating the water and water-soluble protein from the minced meat effectively increases the myofibrillar protein content of frozen surimi. As shown in Fig. 3, when the minced meats were washed in a solution containing either 5 or $15 \mathrm{mM} \mathrm{CaCl}{ }_{2}(I=0.06)$, swelling of the meat was effectively suppressed during the washing processes, thus the water could easily be removed from the washed meat during the following dehydrating process. The myofibrillar protein content of the frozen surimi also increased with increasing $\mathrm{Ca}$ content. It is therefore clear that the myofibrillar protein content of frozen surimi can be increased considerably by $\mathrm{CaCl}_{2}$-washing of the minced meat. In a previous paper, ${ }^{2)}$ we reported that the waterholding capacity of myofibrils decreased considerably when the ionic strength of the solution with suspended myofibrils remained low $(I=0.05-0.10)$ and $\mathrm{Ca}^{2+}$ at a concentration of less than $15 \mathrm{~mm}$ was added. Therefore, the changes in the meat components are assumed to be caused by the decrease in the water-holding capacity of myofibrils caused by $\mathrm{Ca}$ permeated into the fish meat. Further, as shown in Fig. 4, no retardation was found in the elution of water-soluble protein from the washed meats when the materials were suspended in the solution containing $\mathrm{CaCl}_{2}$. This change also increases the myofibrillar protein of frozen surimi. Thus adding $\mathrm{CaCl}_{2}$ during the manufacture of frozen surimi controls the swelling of the washed meat and increases the myofibrillar protein in the product as a result of removing the water-soluble protein by washing the minced meat.

In the mass production of walleye pollack frozen surimi, about $10 \%$ of the myofibrillar protein in minced meat is lost through the screens in the washing process and screw presses in the dehydrating process. ${ }^{13)}$ Some attempts have been made to reclaim the lost fine meat partiles. ${ }^{14}$ As shown in Fig. 6, it is clear that the effluent loss of myofibrillar protein during manufacturing is suppressed by washing the minced meat with $\mathrm{CaCl}_{2}$. Thus the effluence of myofibrillar protein is probably suppressed by preventing the washed meat from swelling and becoming brittle.

This study has shown that $\mathrm{CaCl}_{2}$-washing of minced meat greatly benefits the manufacture of frozen surimi. However, it should be pointed out that the myofibrillar protein is labilized by $\mathrm{CaCl}_{2}$ even at temperatures as low as $10^{\circ} \mathrm{C}$. Thus, it is very important to keep the temperature of the meat during manufacturing as low as possible and to avoid using excess $\mathrm{CaCl}_{2}$.

Acknowledgment We wish to express our thanks to Professor Ken-ich Arai, Faculty of Fisheries, Hokkaido University, for his frequent and helpful discussions.

\section{References}

1) F. Nishioka: Leaching, in "Science and Technology of Fish Paste Products" (ed. by Y. Shimizu), Kouseisya-Kouseikaku, Tokyo, 1984 , pp. $62-73$.

2) H. Saeki, H. Ozaki, M. Nonaka, A. Wakameda, S. Nobuta, and K. Arai: Effect of $\mathrm{CaCl}_{2}$ on water-holding capacity of carp myofibrils and on their thermal stability. Nippon Suisan Gakkaishi, 51, 13111317 (1985).

3) H. Saeki, A. Wakameda, H. Ozaki, M. Nonaka, and K. Arai: Effect of $\mathrm{CaCl}_{2}$ on water-holding capacity of Alaska pollack myofibrils and on their thermal stability. Nippon Suisan Gakkaishi, 52, 1771-1777 (1986).

4) H. Saeki, M. Nonaka, H. Ozaki, and K. Arai: Effect of $\mathrm{CaCl}_{2}$ on water-holding capacity of skipjack myofibrils and on their thermal stability. Nippon Suisan Gakkaishi, 54, 2195-2202 (1988).

5) N. Katoh, H. Uchiyama, S. Tsukamoto, and K. Arai: A biochemical study on fish myofibrillar ATPase. Nippon Suisan Gakkaishi, 43, 857-867 (1977)

6) The Association of Official Anaytical Chemists: Official Analytical Methods of the AOAC, 12th ed., Washington D. C., 1975, p. 22

7) A. G. Gornall, C. J. Bardwill, and M. M. David: Determination of serum proteins by means of the biuret reaction. J. Biol. Chem., 177, $751-766$ (1949).

8) G. Gomori: A modification of the colorimetric phosphorous determination for use with the photoelectric colorimeter. J. Lab. Clinic. Med., 27, 955-960 (1942).

9) N. Katoh, H. Nozaki, K. Komatsu, and K. Arai: A new method for evaluating the quality of frozen surimi from Alaska pollack, Relationship between myofibrillar ATPase activity and kamaboko 
forming ablity of frozen surimi. Nippon Suisan Gakkaishi, 45, 1027-1032 (1979).

10) T. Motohiro and T. Numakura: Actomyosin in frozen minced muscle from sandfish Refrigeration, 49, 953-957 (1974).

11) K. Arai and T. Yamamoto: Frozen Surimi, 1st ed., Nippon Syokuhin Keizaisya, Tokyo, 1986, pp. 81-87.

12) T. Ooizumu, K. Kawasaki, K. Motoe, M. Nonaka, F. Hirata, and H. Saeki: Nutritive component in a new type fish meat for foodstuff (HNFM) from sardine, Nippon Suisan Gakkaishi, 56, 1619-1626
(1990).

13) T. Kawashima and H. Nishida: Studies on advancement of yields and quality preservation of frozen surimi from Alaska pollack. Hokusuishi Geppo, 36, 75-95 (1979).

14) T. C. Lanier, P. K. Manning, T. Zetterling, and G. A. MacDonald: Process innovation in surimi manufacture, in "Surimi Technology" (ed. by T. C. Lanier and C. M. Lee), Marcel Dekker, New York, 1992, pp. 169-174. 